\title{
Photo-Oxygenated Derivatives from Eugenol
}

\author{
A. Mahmoud Dawidar \\ Chem. Dept., Fac. of Sci., \\ Mansoura University \\ Mansoura, Egypt
}

\author{
M. El-Hoseiny Mostafa \\ Chem. Dept., Fac. of Sci., \\ Mansoura University \\ Mansoura, Egypt
}

\author{
M. Mahmoud Abou-Elzahab \\ Chem. Dept., Fac. of Sci., \\ Mansoura University \\ Mansoura, Egypt
}

\author{
N. El-Sayd Youssef \\ Chem. Dept., Fac. of Sci., \\ Mansoura University \\ Mansoura, Egypt
}

\author{
M. Abdel-Mogib \\ Chem. Dept., Fac. of Sci., \\ Mansoura University \\ Mansoura, Egypt
}

\begin{abstract}
Photo-oxygenation reaction was performed on eugenol (1) (2- methoxy-4-(2'-propenyl) phenol) in chloroform as a solvent and tetraphenyl porphrine (TPP) as singlet oxygen sensitizer. Irradiation of the reaction mixture was carried out by sodium lamp at $-20{ }^{\circ} \mathrm{C}$ for six hrs., during which dry oxygen was allowed to pass through the reaction mixture. Two hydroperoxides (3) and (4) were formed. Eugenol methyl ether (2) was also photo-oxygenated under the same conditions of eugenol, where only the side chain was photo-oxygenated at position C-1' to give product (5). In addition to the epoxide derivative of eugenol methyl ester (8) was prepared and its reaction with aminoantipyrine was carried out to give product (9). Product $(\mathbf{8})$ could be considered as a DNA- alkylating agent.
\end{abstract}

Keywords: Eugenol, Photo-oxygenation, Eugenol hydroperoxide, Eugenol methyl ether, Antipyrine, DNAalkylating agent.

\section{INTRODUCTION}

Eugenol, [2-methoxy-4-(2'-propenyl) phenol], a pale yellow liquid is the major constituents of clove essential oil (80-87\%) obtained from the buds of Eugenia caryophyllata (family Myrtaceae) [1]. Eugenol was subjected to extensive biological, medicinal and chemical studies. For example it was reported as antimicrobial [2], antioxidant [3], anticancer [4] and anti-inflammatory agent [5]. Eugenol was also used as a dental medicament due to its analgesic effect [6]. Moreover, it inhibits glulathione- $\delta$-transferase (GST) and cause protection against background damage of liver [7]. Eugenol was converted into 2-methoxy-4-(prop-2en-1-yl) phenyl hydroperoxide by oxidation with $\mathrm{H}_{2} \mathrm{O}_{2}$ under irradiation [1]. Thermal oxidation of eugenol with $3-\mathrm{ClC}_{6} \mathrm{H}_{4} \mathrm{CO}_{3} \mathrm{H}$ at room temperature produced 2-methoxy-4-(oxiran-2-ylmethyl) phenol, while sensitized photochemical oxygenation (using Rose Bengal or chlorophyll) gave 4-hydroperoxy-2methoxy-4-(prop-2-en-1-yl)cyclohexa-2,5-dien-1one [1].

The major photochemical product from eugenol found to be 4-cyclopropy-2-methoxyphenol in addition to 2-(3-methoxy-4 hydroxybenzene)-1methylethyl iso-propyl ether were obtained [8]. On the other hand, when eugenol was exposed to sunlight in iso-propanol for 10 days under atmospheric oxygen, numerous compounds were produced including those produced by irradiation with a mercury lamp [8].

Eugenol was irradiated in a methanol solution for various periods. The main photochemical product was 4-cyclopropyl-2-methoxyphenol (12-28\%). In addition to the cyclopropyl derivative, three methanol solvent addition products, 2-methoxy-4propylphenol (4-7\%), 2-methoxy-4-(2methoxypropyl)phenol (3-7\%), and 2-methoxy-4(1-methoxypropyl) phenol, were formed. The solvent addition products were not obtained when $\mathrm{MeCN}$ was used as a solvent. The eugenol-related compounds, methyleugenol also produced cyclopropyl derivatives. 1-cyclopropyl-3,4dimethoxyeugenol upon photochemical irradiation. The photochemical reaction mechanisms of eugenol are postulated to be di- $\pi$-methane rearrangement, disproportionation reaction, and addition reaction. The cyclopropyl derivatives possessed an interesting floral, spicy odor [9].

Due to the versatile medicinal and pharmaceutical applications of eugenol, we wish to report here our obtained results of eugenol photo-oxygenation reaction in addition to its methyl ether. 


\section{EXPERIMENTAL}

\subsection{General}

Ultraviolet spectra were recorded on a Unicam UV 2100 ultraviolet spectrophotometer. Infrared Spectra were performed on a Unicam Sp 2000 infrared spectrophotometer. ${ }^{1} \mathrm{H}-\mathrm{NMR}$ Spectra were obtained in $\mathrm{CDCl}_{3}$ on Brucker $250 \mathrm{MHz}$ apparatus. The photolysis apparatus used are a sodium lamp (phillips G/5812 SON) and a tungsten-halogen lamp (Lohuis R75). Thin layer chromatography (TLC): polygram SIL G/UV $254 \mathrm{~nm}$, Macherey-Nagel. Column chromatography: silca gel 60 (0.063-0.200 $\mathrm{mm})$, Merck. For the removal of the solvent a rotatory evaporator (at $20^{\circ} \mathrm{C} / 15$ torr) was used.

\subsection{Isolation of eugenol}

The volatile clove oil was extracted from clove (Eugenia caryophyllusi) by steam distillation. Eugenol was isolated by treatment of the extracted oil with an aqueous sodium hydroxide solution (3$5 \%)$. The non-phenolic constituents were extracted with chloroform. The aqueous alkaline solution was acidified with dilute hydrochloric acid to give eugenol (1) (80-87\%), which was extracted by chloroform.

\subsection{Methylation of eugenol}

A solution of eugenol (1) (2 gm) in acetone $(8 \mathrm{ml})$ and in the presence of sodium hydroxide $(20 \mathrm{ml}$, $56 \%$ ) was stirred on an ice bath. During the stirring, dimethyl sulphate $(2 \mathrm{ml})$ was added dropwise to the reaction mixture which was stirred for 6 hours, then poured on ice cold water. Methyl eugenol ether (2) was extracted with chloroform $(3 \times 20 \mathrm{ml})$, washed with water $(3 \times 20 \mathrm{ml})$ and dried over anhydrous sodium sulphate. The solvent $\left(\mathrm{CHCl}_{3}\right)$ was evaporated under reduced pressure to give methyl eugenol ether (2) as a pale yellow oil (1.604 gm, $80 \%$ yield).

\subsection{Photo-oxygenation of eugenol (1)}

A solution of $\mathbf{1}(1 \mathrm{gm})$ and $2 \mathrm{mg}$ tetraphenyl porphrine (TPP) in $\mathrm{CHCl}_{3}(20 \mathrm{ml})$ was irradiated externally by means of a sodium lamp (Phillips $\mathrm{G} / 5812 \mathrm{SON}$ ) at $-20{ }^{\circ} \mathrm{C}$ for 6 hours. During the irradiation a continuous steam of dry oxygen gas was allowed to pass through the reaction mixture at a slow rate to avoid the solvent evaporation (TLC, peroxide test by $\mathrm{KI}, 10 \%)$. The solvent was removed at $20^{\circ} \mathrm{C} / 0.1$ Torr to give gummy material. The crude products were purified by column chromatography on silica gel by elution with a solvent mixture of petroleum ether $60-80^{\circ} \mathrm{C}$ and ethyl acetate (4:1) to give eugenol hydroperoxide derivative (3) (150 mg, 15\% yield) and eugenol dihydroperoxide derivative (4) (80 mg 8\% yield), both were obtained as pale yellow oils.

\subsection{Photo-oxygenation of methyl eugenol ether (2)}

A solution of 2 (1 gm) was photooxygenated as in the case of $\mathbf{1}$. The crude product was purified by column chromatography as above to give the methyl eugenol hydroperoxide derivative (5) as the sole oily product.

\subsection{Photo-irradiation of eugenol dihydroperoxide derivatives (4)}

A solution of (4) $(0.5 \mathrm{gm})$ in benzene $(20 \mathrm{ml})$ was irradiated externally by means of tungsten- halogen lamp at room temperature for 10 hours. Ferric chloride test of the reaction mixture showed phenol was formed. The solvent was removed under reduced pressure to give a gummy material, which was purified by column chromatography, on silica gel adsorbent. Elution of the column with the solvent mixture of petroleum ether $60-80{ }^{\circ} \mathrm{C}$ and ethyl acetate (4:1) yielded eugenol dihydroxide derivative (6) as a viscous oil.

\subsection{Photo-irradiation of methyl eugenol hydroperoxide derivative (5)}

A solution of $5(0.5 \mathrm{gm})$ in benzene $(20 \mathrm{ml})$ was irradiated as in the case of $\mathbf{4}$. Ferric chloride test of the reaction mixture showed phenol formation. The purification of the crude photo- product (6) was carried out as in the case of $\mathbf{6}$ where it gave methyl eugenol hydroxide derivative (7) as viscous oil.

\subsection{Epoxidation of methyl eugenol ether (2)}

A solution of $2(0.8 \mathrm{~g}, 5 \mathrm{mmol})$ in $\mathrm{CHCl}_{3}(25 \mathrm{ml})$ was added portionwise to $m$-chloroperbenzoic acid (CPBA) $(10 \mathrm{mmol}, 80 \%)$ at $0{ }^{\circ} \mathrm{C}$. The reaction mixture was stirred at room temperature (TLC, peroxide test by $\mathrm{KI}, 10 \%)$. It was washed with a saturated aqueous solution of $\mathrm{NaHCO}_{3}(3 \times 10 \mathrm{ml})$, then with distilled water $(3 \mathrm{xl} 0 \mathrm{ml})$. The organic layer was separated, dried over anhydrous $\mathrm{Na}_{2} \mathrm{SO}_{4}$ and evaporated under reduced pressure at room temperature. The crude residue product was purified by column chromatography on silica gel adsorbent. Elution of the column with the solvent mixture petroleum ether $60-80{ }^{\circ} \mathrm{C}$ and ether (9:2) gave eugenol epoxide (8) as viscous oil.

\subsection{Treatment of epoxide derivative (8) with antipyrine}

A mixture of epoxide (8) and antipyrine $(0.168 \mathrm{~g}$ $1.2 \mathrm{mmol}$ ) was fused at $120{ }^{\circ} \mathrm{C}$ for $20 \mathrm{~min}$. The crude product was recrystallized from ethanol to give the adduct (9) as gummy brown material (0.0293 g, $60 \%$ yield). 
Spectral data of compound (1):

UV (Ethanol), $\lambda$ max: 232, 289 and $342 \mathrm{~nm}$

IR (Thin Film), v: 3543, 3019, 2938, 2847, 1609, 1513 and $1145 \mathrm{~cm}^{-1}$

${ }^{1} \mathrm{H}-\mathrm{NMR}\left(\mathrm{CDCl}_{3}\right), \delta$ ppm: $6.92(\mathrm{~d}, 1 \mathrm{H}, \mathrm{J}=10 \mathrm{~Hz}, \mathrm{H}-$ 9), $6.92(\mathrm{~m}, 2 \mathrm{H}, \mathrm{H}-5,8), 6.0(\mathrm{~m}, 1 \mathrm{H}, \mathrm{H}-2), 5.80(\mathrm{~s}$, $1 \mathrm{H}, \mathrm{OH}), 5.20(\mathrm{~m}, 1 \mathrm{H}, \mathrm{H}-\mathrm{la}), 5.10(\mathrm{~s}, 1 \mathrm{H}, \mathrm{H}-1 \mathrm{~b})$, $3.90\left(\mathrm{~s}, 3 \mathrm{H}, \mathrm{OCH}_{3}\right.$ and $3.40(\mathrm{~m}, 2 \mathrm{H}, \mathrm{H}-3)$.

\section{Spectral data of compound (2):}

UV (Ethanol), $\lambda$ max: 233,280 and $349 \mathrm{~nm}$ IR $\left(\mathrm{CHCl}_{3}\right), v:$ 3076, 3017, 2937, 2836, 1620, 1592, 1514 , and $1146 \mathrm{~cm}^{-1}$

${ }^{1} \mathrm{H}-\mathrm{NMR}\left(\mathrm{CDCl}_{3}\right), \delta$ ppm: $6.70(\mathrm{~d}, 1 \mathrm{H}, \mathrm{J}=10 \mathrm{~Hz}, \mathrm{H}-$ 9), 6.65 (m, 2H, H-5,8), 5.9 (m, 1H, H-2), 5.05 (m, $1 \mathrm{H}, \mathrm{H}-1 \mathrm{a}), 5.00$ (s, 1H, H-1b), $3.78\left(\mathrm{~s}, 3 \mathrm{H}, \mathrm{OCH}_{3}\right)$, $3.76\left(\mathrm{~s}, 3 \mathrm{H}, \mathrm{OCH}_{3}\right)$ and $3.30(\mathrm{~m}, 2 \mathrm{H}, \mathrm{H}-3)$.

\section{Spectral data of compound (3):}

UV (Ethanol), $\lambda$ max: 236, 278 and $414 \mathrm{~nm}$ IR $\left(\mathrm{CHCl}_{3}\right), v: 3540,3469,3074,3014,2939,2847$, 1640 , and $1608 \mathrm{~cm}^{-1}$

${ }^{1} \mathrm{H}-\mathrm{NMR}\left(\mathrm{CDCl}_{3}\right), \delta$ ppm: 7.30 (s, $\left.1 \mathrm{H}, \mathrm{OOH}\right), 6.63$ (d, 1H, H-9), 6.15 (d, 1H, H-8), 5.60 (m, 1H, H-2), $5.50(\mathrm{~s}, 1 \mathrm{H}, \mathrm{H}-5), 5.14$ (s, 1H, H-1a), $5.07(\mathrm{~m}, 1 \mathrm{H}$, $\mathrm{H}-1 \mathrm{~b}), 3.80\left(\mathrm{~s}, 3 \mathrm{H},-\mathrm{OCH}_{3}\right)$ and $2.60(\mathrm{~m}, 2 \mathrm{H}, \mathrm{H}-3)$.

\section{Spectral data of compound (4):}

UV (Ethanol), $\lambda$ max: 236, 278, 348, and $414 \mathrm{~nm}$ IR $\left(\mathrm{CHCl}_{3}\right), v: 3540,3433,3014,2939,2847,1640$, 1608 and $1512 \mathrm{~cm}^{-1}$

${ }^{1} \mathrm{H}-\mathrm{NMR}\left(\mathrm{CDCl}_{3}\right), \delta \mathrm{ppm}: 8.6(\mathrm{~s}, 1 \mathrm{H}, \mathrm{OOH}), 7.70$ $(\mathrm{m}, 1 \mathrm{H}, \mathrm{H}-2), 7.5(\mathrm{~d}, 1 \mathrm{H}, \mathrm{H}-3), 6.80(\mathrm{~d}, 1 \mathrm{H}, \mathrm{H}-9)$, $6.40(\mathrm{~d}, 1 \mathrm{H}, \mathrm{H}-8), 6.70(\mathrm{~s}, 1 \mathrm{H},-\mathrm{OOH}), 5.00(\mathrm{~s}, 1 \mathrm{H}$, $\mathrm{H}-5), 4.20(\mathrm{~d}, 2 \mathrm{H}, \mathrm{H}-\mathrm{l})$ and $3.85\left(\mathrm{~s}, 3 \mathrm{H},-\mathrm{OCH}_{3}\right)$.

\section{Spectral data of compound (5):}

UV (Ethanol), $\lambda$ max: 272, 291, 314, 336, 414, 480, $512,546,590$ and $654 \mathrm{~nm}$

IR $\left(\mathrm{CHCl}_{3}\right), v: 3540,3027,2938,1600,1514 \mathrm{~cm}^{-1}$ ${ }^{1} \mathrm{H}-\mathrm{NMR}\left(\mathrm{CDCl}_{3}\right), \delta \mathrm{ppm}: 7.71(\mathrm{~m}, 1 \mathrm{H}, \mathrm{H}-2), 7.53$ (d, 1H, H-3), 6.85 (d, 1H, H-9), 6.70 (m, 2H, H-5, 8), 6.35 (s, 1H, -OOH), 4.30 (m, 2H, H-1), 3.87 (s, $\left.3 \mathrm{H},-\mathrm{OCH}_{3}\right)$ and $3.86\left(\mathrm{~s}, 3 \mathrm{H},-\mathrm{OCH}_{3}\right)$.

\section{Spectral data of compound (6):}

UV (Ethanol), $\lambda$ max: 274, 299, 311 and $415 \mathrm{~nm}$ IR $\left(\mathrm{CHCl}_{3}\right), v: 3500,3100,2980,1720,1600$ and $1500 \mathrm{~cm}^{-1}$

${ }^{1} \mathrm{H}-\mathrm{NMR}\left(\mathrm{CDCl}_{3}\right), \delta \mathrm{ppm}: 7.70(\mathrm{~m}, 1 \mathrm{H}, \mathrm{H}-2), 7.50$ (d, 1H, H-3), 6.85 (d, 1H, H-9), 6.40 (d, 1H, H-8), $5.90(\mathrm{~s}, 1 \mathrm{H}, \mathrm{OH}), 5.00(\mathrm{~s}, 1 \mathrm{H}, \mathrm{H}-5), 4.30(\mathrm{~s}, 1 \mathrm{H}$, $\mathrm{OH}), 4.1(\mathrm{~d}, 2 \mathrm{H}, \mathrm{H}-1)$ and $3.8\left(\mathrm{~s}, 3 \mathrm{H},-\mathrm{OCH}_{3}\right)$.

\section{Spectral data of compound (7): \\ UV (Ethanol), $\lambda$ max: 271, 314, 330, 348 and 409 $\mathrm{nm}$ \\ IR $\left(\mathrm{CHCl}_{3}\right)$, v: $3500,3150,2960,1600$ and 1500 $\mathrm{cm}^{-1}$ \\ ${ }^{1} \mathrm{H}-\mathrm{NMR}\left(\mathrm{CDCl}_{3}\right), \delta \mathrm{ppm}: 7.70(\mathrm{~m}, 1 \mathrm{H}, \mathrm{H}-2), 7.50$ (d, 1H, H-3), 6.80 (d, 1 H, H-9), 6.70 (m, 2H, H- 8, 5), $3.90(\mathrm{~m}, 2 \mathrm{H}, \mathrm{H}-\mathrm{l}), 3.85\left(\mathrm{~s}, 3 \mathrm{H},-\mathrm{OCH}_{3}\right), 3.83(\mathrm{~s}$, $\left.3 \mathrm{H},-\mathrm{OCH}_{3}\right)$ and $3.55(\mathrm{~s}, 1 \mathrm{H}, \mathrm{OH})$.}

\section{Spectral data of compound (8):}

UV (Ethanol), $\lambda$ max: 234, 274, 284, and $376 \mathrm{~nm}$
IR $\left(\mathrm{CHCl}_{3}\right), v: 3017,2939,2915,2838,1593$ and $1514 \mathrm{~cm}^{-1}$

${ }^{1} \mathrm{H}-\mathrm{NMR}\left(\mathrm{CDCl}_{3}\right): \delta \mathrm{ppm}=6.8(\mathrm{~m}, 3 \mathrm{H}, \mathrm{H}-5,8,9$.$) ,$ $3.88\left(\mathrm{~s}, 3 \mathrm{H},-\mathrm{OCH}_{3}\right), 3.86\left(\mathrm{~s}, 3 \mathrm{H},-\mathrm{OCH}_{3}\right), 3.13(\mathrm{~m}$, $1 \mathrm{H}, \mathrm{H}-2), 2.80$ (d, 2H, H-3), 2.76 (dd, 1H, H-1 a) and $2.53(\mathrm{dd}, 1 \mathrm{H}, \mathrm{H}-1 \mathrm{~b})$.

\section{Spectral data of compound (9):}

UV (Ethanol), $\lambda$ max: 271, 300, 314 and $367 \mathrm{~nm}$

IR $\left(\mathrm{CHCl}_{3}\right), v: 3408,3060,2983,2873,1642,2592$ and $1495 \mathrm{~cm}^{-1}$.

${ }^{1} \mathrm{H}-\mathrm{NMR}\left(\mathrm{CDCl}_{3}\right), \delta$ ppm: $7.4(\mathrm{~m}, 3 \mathrm{H}), 7.2(\mathrm{~m}, 2 \mathrm{H}$, arom.), $6.75(\mathrm{~m}, 3 \mathrm{H}, \mathrm{H}-5,8,9), 3.80\left(\mathrm{~s}, 3 \mathrm{H}, \mathrm{CH}_{3}\right)$, $3.77\left(\mathrm{~s}, 3 \mathrm{H},-\mathrm{OCH}_{3}\right), 3.1(\mathrm{~m}, 1 \mathrm{H}, \mathrm{H}-2), 2.76(\mathrm{~s}, 3 \mathrm{H}$, $\left.\mathrm{CH}_{3}\right), 2.87(\mathrm{~s}, 1 \mathrm{H}, \mathrm{OH}), 2.73(\mathrm{~d}, 2 \mathrm{H}, \mathrm{H}-3), 2.65$ (d, $2 \mathrm{H}, \mathrm{H}-1), 2.1(\mathrm{~s}, 1 \mathrm{H}, \mathrm{NH})$ and $2.06\left(\mathrm{~s}, 3 \mathrm{H}, \mathrm{N}-\mathrm{CH}_{3}\right)$.

\section{RESULTS AND DISCUSSIONS}

Schunk and his group in 1988 reported that irradiation of eugenol by low pressure mercury lamp using isopropanol as a solvent produced two photolytic products that were identified as cyclopropyl-2-methylphenol and 2-(3-methoxy-4hyderoxybenzene)-1-methylethyl isopropyl ether [8]. In our work, eugenol was isolated from clove buds (c.f. experimental part) and subjected for photo-oxygenation reaction in chloroform and in presence of (TPP) as a singlet oxygen sensitizer. It was irradiated externally by a sodium lamp at -20 ${ }^{\circ} \mathrm{C}$ for six hrs. Eugenol hydroperoxide (3) and eugenol dihydroperoxide (4) were formed in the reaction mixture. These products were further purified using $\mathrm{CC}$ and their structures were proved using IR and ${ }^{1} \mathrm{H}$ - NMR spectroscopy.

IR spectrum of eugenol monohydropreoxide (3) revealed the presence of absorption bands at 3540 , 1640 and $1608 \mathrm{crn}^{-1}$ corresponding to hydroperoxide $(-\mathrm{OOH})$, carbonyl $(\mathrm{CO})$ and $(\mathrm{C}=\mathrm{C})$ groups respectively. The ${ }^{1} \mathrm{H}-\mathrm{NMR}$ spectrum indicated the presence of doublet signals at $\delta 6.63$ and 6.15 ppm for cyclic $\mathrm{AB}$ system at C-8 and C-9. A singlet signal at $7.3 \mathrm{ppm}$ was assigned for the hydroperoxide group (-OOH).

The IR spectrum of eugenol dihydropreoxide (4) was identical with that of eugenol monohydropreoxide (3). In the ${ }^{1} \mathrm{H}-\mathrm{NMR}$ spectrum two signals as singlet at 8.6 and $6.7 \mathrm{ppm}$ were assigned for two hydroperoxide groups. It is interesting to consider the bifunctionality of eugenol towards the reaction with singlet oxygen. From the previous photo-oxygenation reaction, we have seen that the singlet oxygen may either react at the phenolic site to produce the dienone hydroperoxide [10] or at the allylic site to afforded the corresponding allylic hydroperoxides through the ene reaction [11]. The observed mode of selectivity is however, exclusive formation of (3). Subsequent photo-oxygenation of (3) led to the formation of bishydroperoxyde (4), in which now the ene reactivity manifests itself (Scheme 1). Such mode of selectivity between phenolic site reactions versus allylic ene site reaction appears unprecedented. A possible rational for this mode of selectivity might be due to the higher nucleophilicity of the phenloic versus the allylic site in eugenol. It was believed 
that the singlet oxygen in the lowest unoccupied molecular orbital (LUMO) was combined with the diene group in the benzene ring in the highest occupied molecular orbital (HOMO) as [4+2] cycloaddition through suprafacial - antraficial approach. Whereas, the ene mechanism happened through the formation of peroxirane transition state.

On the other hand, the phenolic site of eugenol was blocked by replacing the phenolic $\mathrm{OH}$ group by methoxy group (methyl eugenol ether (2). The eugenol methyl ether was subjected to photooxygenation reaction with the same conditions for eugenol. The expected methyl eugenol ether hydroperoxide (5) was obtained as a sole product (Scheme 2). The IR spectrum showed absorption band at $3540 \mathrm{~cm}^{-1}$ corresponding to hydroperoxide group $(-\mathrm{OOH})$, which was in agreement with the ${ }^{1} \mathrm{H}-\mathrm{NMR}$ singlet at $\delta 6.36 \mathrm{ppm}$.

The hydroxyl radical $(\cdot \mathrm{OH})$ sources that almost have been applied as DNA cleavage reagents are synthetic ones. Adam and his co-workers were the first to use the natural hydroperoxide derivatives (imperatorine hydroperoxid) for damage DNA photochemically [10]. To explore the search for natural hydroxyl radical sources for DNA-cleavage, the eugenol hydroperoxide derivative (4) was photolysized in benzene as a radical trap in the absence of singlet oxygen sensitizer. This afforded eugenol dihydroxide derivative (6) in addition to phenol. The ${ }^{1} \mathrm{H}-\mathrm{NMR}$ of the photolytic product (6) revealed the presence of two singlets peaks at $\delta 5.90$ and $4.30 \mathrm{ppm}$ for two hydroxyl groups. Similarly, photolysis of methyl eugenol hydroperoxide derivative (5) was carried out under the same conditions used for compound (4), where it afforded the corresponding hydroxyl derivative (7) and phenol. The ${ }^{1} \mathrm{H}-\mathrm{NMR}$ spectrum of product (7) indicated a signal at $3.55 \mathrm{ppm}$ as singlet for one proton assigned for the hydroxylic function group.

In this work, it has been proven that the new eugenol hydroperoxide (3), dihydroperoxide (4) and eugenol methyl ether hydroperoxide derivatives (5) affording the corresponding hydroxyl products $(\mathbf{6}$, 7) upon the photolysis under the conditions stated. Therefore, the photolytic products (6), and (7) are expected to be hydroxyl radical generators in skin when these are treated with DNA under the known irradiation conditions.

The efficiency of the epoxides as DNA- alkylating agents is well known [11]. Thus, methyl eugenol epoxide (8) which was prepared from compound (2) using $m$-chlorobenzoic acid (CPBA) was proven from its ${ }^{1} \mathrm{H}$ - NMR spectrum (c.f experimental part). It is believed that an epoxide such as compound (8) features a new type of alkylating agent for DNA. The aminoantipyrine derivative (9) was prepared by fusion of compound (8) with aminoantipyrine. The IR spectrum of (9) showed the presence of an $\alpha, \beta$ unsaturated carbonyl group at $1642 \mathrm{~cm}^{-1}$. Its ${ }^{1} \mathrm{H}-$ NMR showed signals at $3.80 \mathrm{ppm}$ and $3.77 \mathrm{ppm}$ as singlets which were assigned for the two methoxy groups, in addition to signals for the olefinic methyl and $\mathrm{CH}_{3}-\mathrm{N}$ appeared at 2.76 and $2.06 \mathrm{ppm}$ respectively.

From the present work, it has been shown that a DNA- alkylating agent was prepared from the natural product eugenol and made available for application and investigation of its genotoxic potentiality.<smiles>C=CCc1ccc(O)c(OC)c1</smiles>

(1)<smiles>COC1=CC(O)(/C=C/CO)C=CC1=O</smiles>

(4)

Scheme 1

(3)<smiles>Oc1ccccc1</smiles>

hv

Benzene<smiles>COC1=CC(O)(/C=C/CO)C=CC1=O</smiles>

(6) 


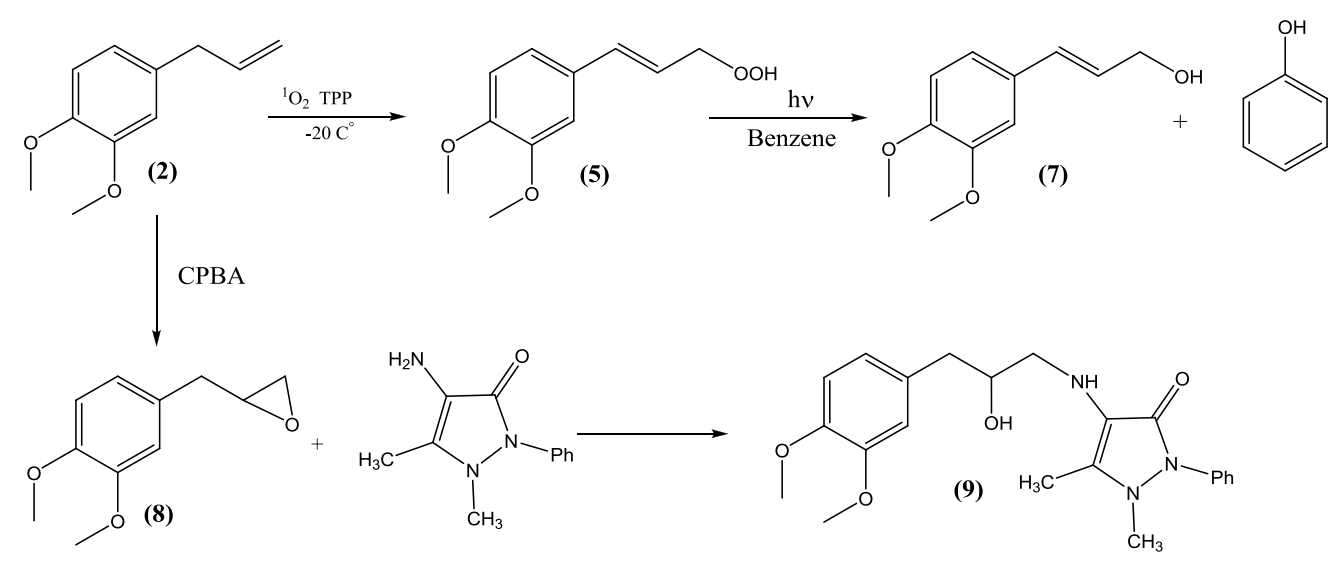

Scheme 2

\section{REFERENCES}

[1] Elgendy, E. M., Khayyat, S. A. (2008) Oxidation Reactions of Some Natural Volatile Aromatic Compounds: Anethole and Eugenol, Russian Journal of Organic Chemistry, vol 44, issue (6), pp 823-829.

[2] Adebajo, A. C., Oloke, K. J., Aladesanmil, A. J. (1989) Antimicrobial activities and microbial transformation of volatile oils of Eugenia uniflora, Fitoterapia, vol 60, pp 451-455.

[3] Iwasaki, M., Ishikawa, C., Maesuura, Y., Ohhashi, E., Harada, R. (1984) Antioxidants of all spices and clove, Sagami Joshi Daigaku Kiyo, vol 48, pp 1-6.

[4] Rompelberg, C. J. M., Stenhuis, W. H., de Vogel, N., Van Osenbruggen, W. A., Schouten, A., Verhagen, H. (1995) Antimutagenicity of eugenol in the rodent bone marrow micronucleus test, Mutat. Res., vol 346, pp 69-75.

[5] Bennett, A., Stamford, I. F., Tavares, L. A., Jacobs, S., Cappasso, F., Mascolo, N., Autore, G., Romano, V., Di Carlo, G. (1988) The biological activity of eugenol, a major constituent of nutmeg (Myristica fragrans): Studies on prostaglandins, the intestine and other tissues, Phytother. Res., vol 2, issue (3), pp 124-130.
[6] Hirafuji, M. (1984) Inhibition of prostaglandin I2 biosynthesis in rat dental pulp by phenolic dental medicaments, Jpn. J. Pharmacol., vol 36, issue (4), pp 544-546.

[7] Rompelberg, C. J. M., Vogles, J. T. W. E., de vogel, N., Bruijntjes-Rozier, G. C. D. M., Stenhuis, W. H., Bogaards, J. J. P., Verhagen, H. (1996) Effect of short-term dietary administration of eugenol in humans, Hum. Exp. Toxical., vol 12, pp 129-135.

[8] Schunk, H. H., Shibamoto, T., Tan, H. K., Wei, change-L. (1988), Dev. Food Sci, vol 18, pp 1045.

[9] Mihara, S., Shibamoto, T. (1982) Photochemical reactions of eugenol and related compounds: Synthesis of new flavor chemicals, J. Agric. Food Chem., vol 30, issue (6), pp 1215-1218.

[10] Adam, W., Lupon, P. (1988) Quinol epoxides from $\mathrm{p}$-cresol and estrone by photooxygenation and titanium (IV)-or vanadium (V)-catalyzed oxygen transfer, Chem. Ber., vol 121, pp 2125.

[11] Orfanopoulos, M., Grdina, M. B., Stephenson, L. M. (1980), J. Am. Chem. Soc., vol 102, pp1738. 